\section{OPEN ACCESS}

Edited by:

Robson Coutinho-Silva, Federal University of Rio de Janeiro,

Brazil

Reviewed by: Luigi Cari,

University of Perugia, Italy

Rui Li,

University of Pennsylvania,

United States

*Correspondence:

Girolamo Pelaia

pelaia@unicz.it

Specialty section:

This article was submitted to Inflammation,

a section of the journal

Frontiers in Immunology

Received: 06 September 2020 Accepted: 03 November 2020

Published: 30 November 2020

Citation:

Pelaia C, Crimi C, Vatrella A, Tinello C, Terracciano $R$ and Pelaia G (2020) Molecular Targets for Biological Therapies of Severe Asthma.

Front. Immunol. 11:603312. doi: 10.3389/fimmu.2020.603312

\title{
Molecular Targets for Biological Therapies of Severe Asthma
}

\author{
Corrado Pelaia ${ }^{1}$, Claudia Crimi ${ }^{2}$, Alessandro Vatrella ${ }^{3}$, Caterina Tinello ${ }^{4}$, \\ Rosa Terracciano ${ }^{5}$ and Girolamo Pelaia ${ }^{6 *}$ \\ ${ }^{1}$ Respiratory Medicine Unit, University "Magna Græcia" of Catanzaro, Catanzaro, Italy, 2 Department of Clinical and \\ Experimental Medicine, University of Catania, Catania, Italy, ${ }^{3}$ Department of Medicine, Surgery and Dentistry, University of \\ Salerno, Salerno, Italy, ${ }^{4}$ Pediatrics Unit, Provincial Outpatient Center of Catanzaro, Catanzaro, Italy, ${ }^{5}$ Department of \\ Experimental and Clinical Medicine, University "Magna Græcia” of Catanzaro, Catanzaro, Italy, " Department of Health \\ Sciences, University "Magna Græcia" of Catanzaro, Catanzaro, Italy
}

Asthma is a heterogeneous respiratory disease characterized by usually reversible bronchial obstruction, which is clinically expressed by different phenotypes driven by complex pathobiological mechanisms (endotypes). Within this context, during the last years several molecular effectors and signalling pathways have emerged as suitable targets for biological therapies of severe asthma, refractory to standard treatments. Indeed, various therapeutic antibodies currently allow to intercept at different levels the chain of pathogenic events leading to type 2 (T2) airway inflammation. In addition to pro-allergic immunoglobulin E (IgE), that chronologically represents the first molecule against which an anti-asthma monoclonal antibody (omalizumab) was developed, today other targets are successfully exploited by biological treatments of severe asthma. In particular, pro-eosinophilic interleukin 5 (IL-5) can be targeted by mepolizumab or reslizumab, whereas benralizumab is a selective blocker of IL-5 receptor. Moreover, dupilumab behaves as a dual receptor antagonist of pleiotropic interleukins 4 (IL-4) and 13 (IL-13). Besides these drugs that are already available in medical practice, other biologics are under clinical development such as those targeting innate cytokines, also including the alarmin thymic stromal lymphopoietin (TSLP), which plays a key role in the pathogenesis of type 2 asthma. Therefore, ongoing and future biological therapies are significantly changing the global scenario of severe asthma management. These new therapeutic options make it possible to implement phenotype/endotype-specific treatments, that are delineating personalized approaches precisely addressing the individual traits of asthma pathobiology. Such tailored strategies are thus allowing to successfully target the immune-inflammatory responses underlying uncontrolled T2-high asthma.

Keywords: T2-high asthma, IgE, IL-4, IL-5, IL-13, monoclonal antibodies

\section{INTRODUCTION}

Asthma is a very diffuse chronic respiratory disease whose main pathologic features include airway inflammation and remodelling, which are responsible for variable airflow limitation and bronchial hyperresponsiveness (1-3). More than 300 million people currently suffer from asthma worldwide, and this number is probably destined to undergo further increases during the next years $(4,5)$. 
In most subjects with asthma a good disease control can be achieved using standard inhaled treatments. However, about 5$10 \%$ of patients included in the global population of asthmatic individuals experience various subtypes of inadequately controlled and difficult-to-treat asthma (6). In this regard, severe asthma was jointly defined by both European Respiratory Society (ERS) and American Thoracic Society (ATS) as a condition controlled by high dosages of inhaled corticosteroids (ICS)/long-acting $\beta_{2}$-adrenergic agonists (LABA) combinations, which can also require the addition of other drugs (i.e. tiotropium, leukotriene modifiers, oral corticosteroids); even worse, severe asthma might remain uncontrolled despite such massive inhaled and systemic treatments (7). Hence, within the overall spectrum of subjects with asthma, severe asthmatic patients are characterized by the most urgent unmet medical needs and can be eligible to add-on biological therapies (8). The latter mainly consist of already licensed monoclonal antibodies targeting specific molecules involved in the pathobiology of type 2 (T2-high) eosinophilic, allergic and non-allergic asthma, including immunoglobulins E (IgE), interleukin-5 (IL-5) and its receptor, as well as interleukin-4 (IL-4) receptor (9-11). Other experimental biologics target upstream innate cytokines such as thymic stromal lymphopoietin (TSLP) $(12,13)$. Conversely, current pharmacotherapeutic pipelines are very scarce with regard to investigational drugs directed against molecular targets implicated in the pathogenesis of T2-low, mostly neutrophilic severe asthma. Therefore, a careful characterization of the biological mechanisms (endotypes) underlying the different phenotypes plays a key role in driving the clinical choice of the most appropriate add-on therapy for each individual patient with severe asthma $(14,15)$.

On the basis of the above considerations, the aim of this review article is to outline the cellular and molecular pathophysiology of severe asthma, in order to provide a logical premise for the subsequent discussion of the current and future biological strategies that can be used to treat the patients with uncontrolled disease.

\section{PATHOBIOLOGY OF SEVERE ASTHMA}

Asthma is a heterogeneous disease, originating from complex interactions between genetic and environmental factors, which consists of several different phenotypes sustained by cytokinebased biological mechanisms known as endotypes $(16,17)$. The inflammatory endotypes include eosinophilic, neutrophilic, mixed and paucigranulocitic cellular patterns (2, 18-22). In particular, T2-high eosinophilic inflammation is quite common in patients with either allergic or non-allergic asthma, and can frequently characterize severe and fatal disease (23-27).

T2-high eosinophilic allergic asthma, occurring especially in children and adolescents, develops as a consequence of an intricate cross-talk between innate and adaptive immune responses (28). In particular, allergic asthma is triggered by dust mites, tree pollen and animal dander, which within the airways are captured by dendritic cells that internalize and process these aeroallergens, and also transport them to thoracic lymph nodes. Here, dendritic cells expose on their surface the processed allergen peptides and, within the context of specific HLA class II molecules of the major histocompatibility complex (MHC class II), operate antigen presentation to the T-cell receptors of naïve $\mathrm{CD}^{+} \mathrm{T}$ lymphocytes, thus inducing their polarization towards the T helper 2 (Th2) lineage (1). This event is driven by interleukin-4 (IL-4) produced by mast cells and basophils, and is also dependent on selective reciprocal recognition of specific co-stimulatory molecules located on the plasma membranes of dendritic cells (CD80/B7.1, CD86/B7.2, OX40 ligand, ICOS ligand) and T lymphocytes (CD28, OX40, ICOS), respectively $(29,30)$. As a result of such a complex process of differentiation and activation, mature Th2 cells secrete large quantities of IL-4, IL-13, and IL-5. IL-13 and especially IL-4 induce Ig class switching by stimulating $\mathrm{B}$ lymphocytes to synthesize allergen-specific immunoglobulins E (IgE), which bind to high-affinity (FceRI) and lowaffinity (CD23/FceRII) receptors present on both immune/ inflammatory and structural cells of the respiratory tract (3134). These adaptive immune pathways are crucially integrated by innate immune mechanisms involving important functions of airway epithelial cells and innate lymphoid cells, as well as further contributions of dendritic cells $(35,36)$. Indeed, aeroallergens, respiratory viruses, cigarette smoking and airborne pollutants induce bronchial epithelial cells to produce the innate cytokines thymic stromal lymphopoietin (TSLP), interleukin-25 (IL-25) and interleukin-33 (IL-33), that in turn potentiate Th2-mediated adaptive immune responses and promote the release of IL-4, IL-13, and IL-5 from Th2 lymphocytes and group 2 innate lymphoid cells (ILC2) (37). Another relevant cellular source of IL-4 is represented by $\mathrm{T}$ follicular helper cells (Tfh), whose development in lung-draining lymph nodes depends on TSLP-induced activation of dendritic cells expressing OX40 ligand (38). Dendritic cells also secrete CCL17 and CCL22 chemokines, that selectively interact with CCR4 receptors expressed by mature Th2 lymphocytes, thus promoting their migration from thoracic lymph nodes to the airways (39).

In regard to the functions of Th2 cytokines, IL-4 drives IgE biosynthesis, IL-13 mainly contributes to mucus production, airway remodelling and bronchial hyperresponsiveness, and IL5 is the key inducer of eosinophil differentiation, activation and survival $(17,40)$. In addition to Th2 lymphocytes, IL-5 is also produced by mast cells, natural killer $\mathrm{T}$ cells, eosinophils themselves and especially ILC2, the latter being the main cellular orchestrators of non-allergic eosinophilic asthma (4042), frequently characterized by a late onset in adulthood. IL-5 is responsible for eosinophil maturation, and in asthmatic patients this eosinophilopoietic action occurs not only in the bone marrow, but also in bronchial mucosa (43-45). Indeed, IL-5 concentrations and the numbers of both mature eosinophils and eosinophil progenitors are increased in induced sputum from asthmatic subjects. High IL-5 levels can be also detected in serum, especially when obtained from patients with severe 
asthma (46). Moreover, IL-5 exerts an inhibitory effect on eosinophil apoptosis, and the numbers of apoptotic eosinophils are negatively correlated with sputum IL-5 concentrations in stable asthma, as well as during disease exacerbations $(47,48)$. IL-5 also contributes to eosinophil recruitment within asthmatic airways, thereby cooperating with eosinophil chemoattractants such as eotaxins (49). Furthermore, in patients with T2-high asthma IL-5 stimulates the interaction of eosinophils with periostin, an extracellular matrix protein whose expression resulted to be up-regulated during eosinophil migration towards airways (50). Especially in severe asthma, IL-5activated eosinophils also contribute to bronchial structural changes via the release of powerful pro-remodelling mediators such as transforming growth factor- $\beta$ (TGF- $\beta)(51,52)$.

T2-low asthma is often characterized by airway neutrophilia, particularly in patients suffering from severe disease forms (53). In this regard, the Th17 subset of $\mathrm{CD}^{+} \mathrm{T}$ lymphocytes seems to play a pivotal pathogenic role (54-56). Th17 cells produce IL17A and IL-17F, whose expression was shown to be significantly up-regulated in bronchial biopsies from patients with severe asthma (57). Th17 cell development depends on the coordinate actions of IL-1 $\beta$, IL- 6 , and TGF- $\beta$, which are essential for induction of differentiation of this cellular immunophenotype (58-60). In addition, IL-21 produced by Th17 cells themselves plays a key role as autocrine amplifier of Th17 response $(60,61)$. Mature Th17 lymphocytes also express the specific receptor of IL-23, a cytokine which is required to stabilize the Th17 phenotype and to maintain Th17 cells in a state of effective activation (60-62). Cigarette smoke and diesel exhaust particles can induce airway neutrophilia, which was shown to be associated with Th17-dependent severe asthma $(63,64)$. Infectious agents also seem to be able to trigger Th17-mediated severe asthma, and this effect may involve the assembly of the inflammasome, an intracellular multiprotein complex which activates caspase-1, a protease that converts pro-IL-1 $\beta$ in its active form, thus enabling it to induce Th17 cell differentiation $(65,66)$. Inflammasome activation was also shown to be implicated in obesity-associated bronchial hyperresponsiveness (67). In severe asthma, Th17 cell polarization and neutrophilic airway inflammation can also be promoted by neutrophil extracellular traps (NETs), consisting of anti-microbial complexes of extracellular DNA, histones and granular proteins extruded from neutrophils that become anuclear cells known as cytoplasts (68-70). In addition to Th17 lymphocytes, other cellular sources of IL-17 include invariant NK T cells, $\gamma \delta \mathrm{T}$ cells, cytotoxic T cells, and especially group 3 innate lymphoid cells (ILC3) (71, 72). High numbers of ILC3 were found in bronchoalveolar lavage fluid (BALF) from adults with severe asthma, as well as in blood of obese asthmatic children $(72,73)$. Once secreted from Th17 lymphocytes, ILC3 and other cell types, IL-17A and IL-17F induce bronchial epithelial cells and sub-epithelial airway fibroblasts to release potent neutrophil chemoattractants including IL-8 (CXCL8) and CXCL1/GRO- $\alpha$ (74-76]. IL-17-mediated neutrophilic asthma is often associated with a relevant insensitivity to the therapeutic actions of corticosteroids, which indeed exert an anti-apoptotic effect on neutrophils, thus prolonging their survival (77). In addition to Th17 lymphocytes, also IL-12-dependent Th1 cells can contribute to the pathobiology of severe neutrophilic asthma $(59,78)$. In fact, Th1 lymphocyte numbers and the levels of their cytokines such as interferon- $\gamma($ IFN- $\gamma$ ) and tumor necrosis factor- $\alpha$ (TNF- $\alpha)$ are enhanced in severe asthmatic patients (59, 79).

The mixed eosinophilic/neutrophilic inflammatory phenotype is often associated with severe asthma. In particular, circulating Th2/Th17 cell clones producing both IL-4 and IL$17 \mathrm{~A}$ were found in asthmatic patients (80). Moreover, high numbers of dual-positive Th2/Th17 lymphocytes secreting large quantities of IL-4 and IL-17 were detected in BALF from patients with severe asthma (81). Indeed, these BALF lymphocytes were shown to concomitantly express two transcription factors such as GATA3 and ROR $\gamma$ t (81), which are essential for differentiation of Th2 and Th17 cells, respectively. Such observations corroborated the results of previous studies performed in mice, which had demonstrated that Th2/Th17 lymphocytes were involved in the induction of severe forms of experimental asthma (82). Hence, additional studies are needed to further characterize the cellular phenotypes of dual Th2/Th17 lymphocyte subsets, and to better understand if IL-4 and IL-17 produced by these cells could eventually exert additive or synergistic effects, especially in the pathobiology of severe asthma (83).

In addition to eosinophilic, neutrophilic, and mixed granulocytic inflammatory profiles, also paucigranulocytic histopathological patterns have been found in airway biopsies from asthmatic patients $(84,85)$. The cellular pathophysiology of this particular asthmatic phenotype, characterized by the lack of increased counts of eosinophils or neutrophils in either sputum or blood, has not been clearly elucidated. However, it appears that paucigranulocytic asthma is featured by an uncoupling of bronchial obstruction from inflammation, possibly due to structural changes mainly resulting in non-inflammatory thickening of airway smooth muscle layer (86).

\section{LICENSED BIOLOGICAL THERAPIES OF SEVERE ASTHMA}

There are currently five approved monoclonal antibodies for add-on biologic treatment of severe asthma. They include omalizumab, mepolizumab, reslizumab, benralizumab, and dupilumab (Figure 1).

Omalizumab has been the first licensed biologic drug for clinical use in the management of severe asthma. This recombinant humanized monoclonal antibody, originally developed in mice, binds to the two Ce3 domains of the constant portion of IgE, thus forming IgE/anti-IgE immune complexes that prevent IgE interactions with both high-affinity FceRI and low-affinity FceRII/CD23 membrane receptors (87, 88). As a consequence, omalizumab inhibits all IgE-dependent cellular and molecular events involved in the immune/ inflammatory cascade underlying allergic asthma. Systematic 


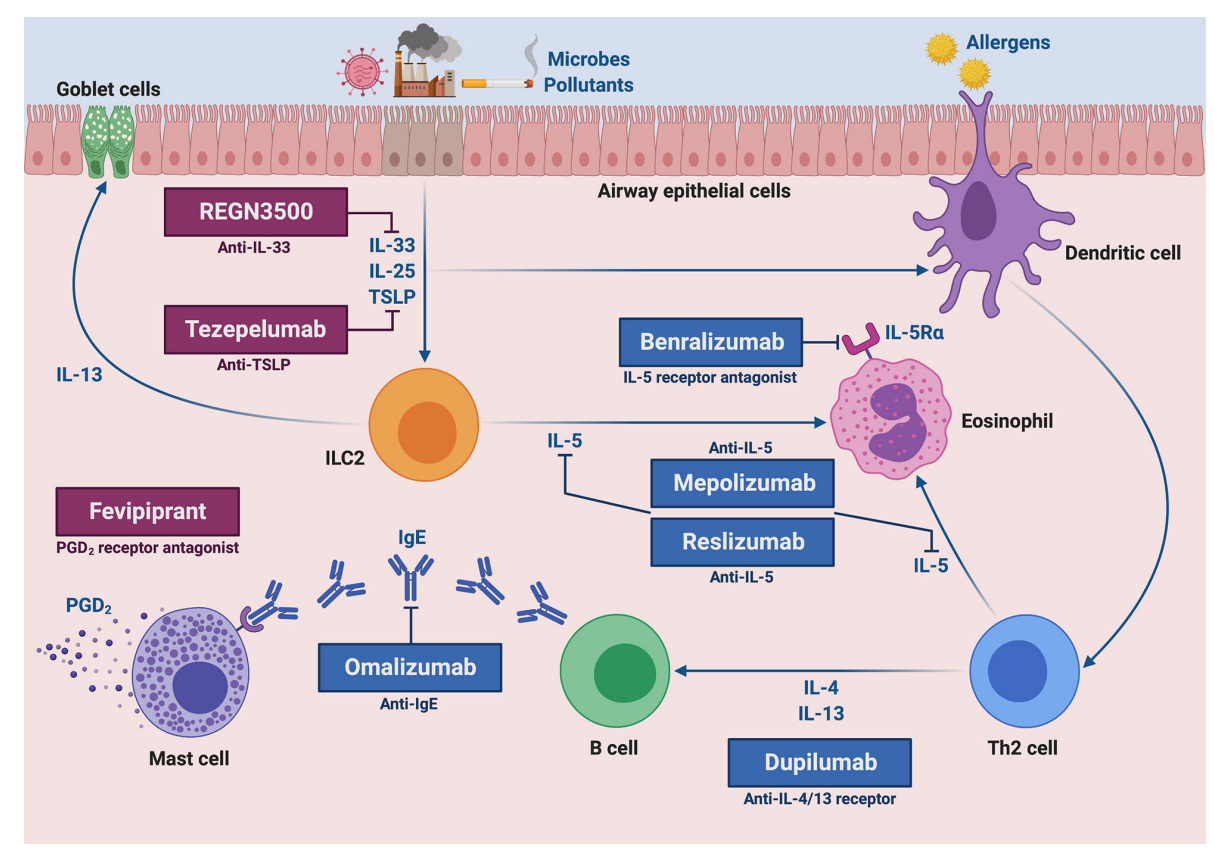

FIGURE 1 | Molecular targets of current and future biological therapies of severe type 2 asthma. The targets of approved add-on biologic treatments (highlighted in blue color) of severe asthma include IgE (omalizumab), IL-5 (mepolizumab and reslizumab), IL-5 receptor (benralizumab), and IL-4/IL-13 receptor complex (dupilumab). Moreover, experimental drugs (highlighted in dark magenta color) such as tezepelumab, REGN3500 and fevipiprant target TSLP, IL-33 and the CRTH2 receptor of $\mathrm{PGD}_{2}$, respectively. This original figure was created by the authors using "BioRender.com".

reviews and pooled analyses of randomized controlled trials have clearly shown that omalizumab was able to significantly decrease the rate of asthma exacerbations, and this therapeutic effect was observed up to $48-60$ weeks of treatment $(89,90)$. Such a favourable clinical outcome has been further corroborated by several worldwide real-life studies (91). In addition to confirming the positive impact of omalizumab on asthma exacerbations, emergency room accesses and hospitalizations, real-world experiences have also demonstrated relevant improvements in symptom control, quality of life, and intake of oral corticosteroids (OCS), as well as a lower loss of working and school days (91-93). Despite some discordant published data regarding the effects of omalizumab on lung function (15), many real-life studies have shown that this anti-IgE monoclonal antibody can induce significant and persistent increases in forced expiratory volume in the first second $\left(\mathrm{FEV}_{1}\right)$, lasting 5 , 7 , and even 9 years (94-96). Moreover, it was also recently reported that omalizumab can effectively improve both clinical manifestations and computed tomography (CT) images of nasal polyps associated with severe allergic asthma (97). All these beneficial outcomes achieved by patients undergoing add-on therapy with omalizumab explain the high degree of adherence to this biologic drug (98). The real-life therapeutic effectiveness of omalizumab coexists with a long-term, very good safety and tolerability profile (99).

Mepolizumab is a humanized $\operatorname{IgG} 1 / \kappa$ monoclonal antibody of murine origin which binds with high affinity to human IL-5, thus preventing its interaction with the $\alpha$ subunit of IL- 5 receptor (IL$5 R \alpha)(100)$. The efficacy of mepolizumab was firstly evidenced by Nair et al. and by Haldar et al., who showed in a few frequent exacerbators with severe eosinophilic asthma that this biologic drug significantly reduced disease exacerbations, as well as blood and sputum eosinophils $(101,102)$. These positive effects of mepolizumab were later confirmed by the phase IIb/III DREAM (Dose Ranging Efficacy And safety with Mepolizumab) trial, carried out by Pavord et al. in a much larger number of patients (103). Moreover, MENSA (MEpolizumab as adjunctive therapy iN patients with Severe Asthma) and SIRIUS (SteroId ReductIon with mepolizUmab Study) trials, performed by Ortega et al., and Bel et al., respectively, documented that in subjects with severe eosinophilic asthma mepolizumab lowered asthma exacerbation rate, improved quality of life and symptom control, and also slightly increased $\mathrm{FEV}_{1}(104,105)$. In addition, the SIRIUS study demonstrated that mepolizumab exerted an effective OCS sparing action, thereby decreasing prednisone intake by $50 \%$ (105). Furthermore, the phase IIIb MUSCA trial, carried out by Chupp et al., corroborated the significant results achieved by patients undergoing add-on mepolizumab therapy with regard to improvement of health-related quality of life (106). All these randomized controlled studies also reported a very good pattern of drug safety and tolerability. Besides such controlled trials, uncontrolled, open-label, and real-life investigations are providing further information about the therapeutic properties of mepolizumab. Indeed, some real-world data suggest that in 
clinical practice mepolizumab effectiveness can be even greater than that one observed in randomized controlled trials, and these better results might be dependent on the higher numbers of baseline blood eosinophils detectable in patients enrolled in reallife experiences $(107,108)$. The latter have shown that mepolizumab is very effective in both non allergic and allergic patients with severe eosinophilic asthma, also in case of switching from omalizumab to mepolizumab because of an inadequate disease control provided by anti-IgE treatment (109-111). With regard to lung function, it is noteworthy that in real-life setting mepolizumab was able not only to increase $\mathrm{FEV}_{1}$, but also to improve airflow limitation at level of small airways (112). Mepolizumab was capable of inducing beneficial therapeutic effects also in severe nasal polyposis, thus improving subjective symptoms and endoscopic nasal polyp score, as well as leading to a decreased need for surgical polypectomy (113).

Another anti-IL-5 biologic drug is reslizumab, a humanized IgG4/ $\kappa$ monoclonal antibody of rat origin, whose clinical and functional effects have been assessed in many randomized trials $(114,115)$. The first phase II trial was conducted by Kips et al., who demonstrated that reslizumab reduced both sputum and blood eosinophil counts, as well as transiently increased $\mathrm{FEV}_{1}$ (116). A further phase II study, performed by Castro et al. in patients with severe eosinophilic asthma, showed that reslizumab induced a significant $\mathrm{FEV}_{1}$ increase, associated with a non-significant tendency towards an improvement in asthma control, particularly in asthmatic subjects with high blood eosinophil numbers and coexistent nasal polyposis (117). Subsequently, two phase III trials carried out by Castro et al. in patients with severe asthma and blood eosinophil counts higher than 400 cells $/ \mu \mathrm{L}$, evidenced that reslizumab lowered the annual asthma exacerbation rate by more than $50 \%$, improved asthma control and incremented $\mathrm{FEV}_{1}$ (118). Such findings were further confirmed by Brusselle et al., especially in subjects with late-onset eosinophilic asthma (119). Moreover, Bjermer et al. observed that the positive effects of reslizumab on lung function were not limited to the large airways, as shown by $\mathrm{FEV}_{1}$ increases, but also extended to the small airways resulting in significant enhancements of midexpiratory flow at $25-75 \%$ of forced vital capacity $\left(\mathrm{FEF}_{25-75}\right)$ (120). Similar to omalizumab and mepolizumab, also reslizumab displays a more than satisfactory profile of safety and tolerability (114).

Differently from mepolizumab and reslizumab, benralizumab is characterized by a dual mechanism of action. Indeed, this humanized afucosylated IgG1/ $\kappa$ monoclonal antibody of murine origin binds through its Fab fragments to IL-5R $\alpha$, thereby impeding the assembly of the ternary molecular complex consisting of IL-5, IL-5R $\alpha$, and the $\beta c$ subunits of IL-5 receptor $(121,122)$; as a consequence, IL-5 cannot exert its biological effects on target cells (eosinophils, basophils, ILC2). Moreover, via the constant Fc portion benralizumab interacts with the surface FcyRIIIa receptor of natural killer cells, thus triggering eosinophil apoptosis operated by antibody-dependent cell-mediated cytotoxicity (ADCC), a mechanism that is remarkably potentiated by afucosylation $(121,122)$. In regard to the randomized clinical trials, phase III SIROCCO and CALIMA studies have demonstrated that benralizumab significantly reduced the annual rate of severe eosinophilic asthma exacerbations, and also bettered asthma symptom control and increased $\operatorname{FEV}_{1}(123,124)$. Chipps et al. performed a pooled analysis of SIROCCO and CALIMA trials, thus showing that benralizumab was effective as adjunctive biological therapy in both allergic and non-allergic patients with severe eosinophilic asthma (125). The BISE trial confirmed the positive impact of benralizumab on lung function, whereas the ZONDA study showed that benralizumab significantly decreased daily OCS intake $(126,127)$. Furthermore, the BORA trial documented that benralizumab use was associated with long-term safety and tolerability (128). All these findings, regarding clinical and functional outcomes, have been corroborated, and even extended and amplified by recent real-life experiences. The latter are providing convincing evidence referring to the safety and efficacy of benralizumab, detected in both atopic and nonatopic subjects with eosinophilic uncontrolled asthma, with regard to relevant improvements in asthma exacerbations, OCS consumption, symptom control, airflow limitation, lung hyperinflation, and nasal polyposis (129-132).

Dupilumab is a fully human IgG4 monoclonal antibody, which specifically recognizes and occupies the $\alpha$ subunit of IL4 receptor, thereby inhibiting the biological actions of both IL-4 and IL-13 (133). Indeed, these two cytokines not only exert overlapping effects related to IgE class switching, eosinophil chemotaxis and airway hyperresponsiveness, but also share common receptor mechanisms and signalling pathways, based on activation of IL- $4 \mathrm{R} \alpha$ coupled to the JAK/TYK transduction machinery $(10,133)$. Therefore, dupilumab behaves as a dual receptor antagonist of IL-4 and IL-13 (134). In an initial phase IIa trial, Wenzel et al. randomly assigned to either dupilumab or placebo 104 patients with persistent, moderate-to-severe eosinophilic asthma, thus showing that dupilumab significantly lowered the asthma exacerbation rate by $87 \%$, and also enhanced $\mathrm{FEV}_{1}$ by more than $200 \mathrm{~mL}$, despite ICS/LABA withdrawal (135). A subsequent larger, phase IIb study carried out in uncontrolled adult asthmatics confirmed the positive impact of dupilumab on asthma exacerbations and lung function, especially but not only in subjects with high blood eosinophil counts (136). More recently, the phase III LIBERTY ASTHMA QUEST trial showed that in asthmatic patients with blood eosinophil numbers $\geq 300$ cells $/ \mu \mathrm{L}$, dupilumab was able to decrease asthma exacerbations by more than $65 \%$, as well as to increase $\mathrm{FEV}_{1}$ by more than $200 \mathrm{~mL}$ (137). Corren et al. performed a post hoc analysis of the LIBERTY ASTHMA QUEST study, thereby demonstrating that the above beneficial effects of dupilumab can be indifferently detected in both allergic and non-allergic asthmatics (138). Furthermore, the LIBERTY ASTHMA VENTURE trial highlighted the significant OCSsparing action of dupilumab (139). Overall, dupilumab is quite safe and well tolerated, even if in some patients this biologic drug can induce conjunctivitis or a marked blood eosinophilia (10), which however tends to resolve spontaneously in a few months, 
TABLE 1 | Licensed biological therapies for severe asthma.

\begin{tabular}{|c|c|c|c|}
\hline $\begin{array}{l}\text { Licensed } \\
\text { biological } \\
\text { therapies }\end{array}$ & Targets & $\begin{array}{l}\text { Molecular mechanisms of } \\
\text { action }\end{array}$ & $\begin{array}{c}\text { Effects in the control } \\
\text { of severe asthma }\end{array}$ \\
\hline Omalizumab & $\lg E$ & $\begin{array}{l}\text { Generation of IgE/anti-lgE } \\
\text { immune complexes that } \\
\text { inhibit IgE-mediated allergic } \\
\text { cascade }\end{array}$ & $\begin{array}{l}\downarrow \text { Exacerbations } \\
\uparrow \text { Quality of life and } \\
\text { symptom control } \\
\uparrow \text { FEV1 }\end{array}$ \\
\hline Mepolizumab & IL-5 & $\begin{array}{l}\text { Prevention of IL-5 binding to } \\
\text { IL- } 5 R \alpha\end{array}$ & $\begin{array}{l}\downarrow \text { Blood and sputum } \\
\text { eosinophils } \\
\downarrow \text { Exacerbations } \\
\uparrow \text { Quality of life and } \\
\text { symptom control } \\
\downarrow \text { OCS intake } \\
\uparrow \text { FEV } 1\end{array}$ \\
\hline Reslizumab & IL-5 & $\begin{array}{l}\text { Prevention of IL-5 binding to } \\
\text { IL- } 5 R \alpha\end{array}$ & $\begin{array}{l}\downarrow \text { Blood and sputum } \\
\text { eosinophils } \\
\downarrow \text { Exacerbations } \\
\uparrow \text { Quality of life and } \\
\text { symptom control } \\
\uparrow \text { FEV1 }\end{array}$ \\
\hline Benralizumab & IL-5R $\alpha$ & $\begin{array}{l}\text { Blockade of IL-5R } \alpha \\
\text { ADCC-induced eosinophil } \\
\text { apoptosis }\end{array}$ & $\begin{array}{l}\downarrow \text { Blood eosinophils } \\
\downarrow \text { Exacerbations } \\
\uparrow \text { Quality of life and } \\
\text { symptom control } \\
\downarrow \text { OCS intake } \\
\uparrow \text { FEV1 }\end{array}$ \\
\hline Dupilumab & IL-4R $\alpha$ & $\begin{array}{l}\text { Dual receptor antagonism of } \\
\text { IL-4/IL-13 }\end{array}$ & $\begin{array}{l}\downarrow \text { Exacerbations } \\
\downarrow \text { OCS intake } \\
\uparrow \text { FEV1 }\end{array}$ \\
\hline
\end{tabular}

without apparent consequences in most cases. Dupilumab is also very effective for treatment of relevant asthma comorbidities such as atopic dermatitis and nasal polyposis (140, 141).

The molecular targets, mechanisms of action and therapeutic effects of the above mentioned drugs are summarized in Table $\mathbf{1}$.

\section{TARGETS OF EMERGING BIOLOGICAL THERAPIES IN CLINICAL DEVELOPMENT}

In addition to the currently available biological therapies of severe asthma, the recent advances in our understanding of the pathobiology of this complex disease are allowing to disclose new potential targets for future anti-asthma treatments. In particular, besides the downstream effectors of type 2 airway inflammation such as IgE, IL-5, IL-4/13 and their receptors, other very interesting pathogenic molecules include upstream activators of cellular pathways leading to T2-high asthma. Within this context, a key role is played by the innate cytokines known as alarmins, including TSLP, IL-33, and IL-25 (142). So far, the most extensively studied alarmin as suitable target for novel biological therapies of asthma has been TSLP $(13,143)$.

TSLP bioactivities are involved in several pathogenic aspects of type 2 asthma. Indeed, by up-regulating OX40 ligand expression, TSLP acts as a powerful inducer of dendritic cell activation (144). Upon TSLP-mediated stimulation, dendritic cells drive naïve Th lymphocytes towards differentiation into active Th2 cells producing IL-4, IL-5, and IL-13 (145). Moreover, TSLP up-regulates the expression of such cytokines at level of other cellular sources, including basophils, mast cells, and especially ILC2 $(142,146,147)$. In regard to these latter cells, TSLP also promotes their survival and steroid resistance (147, 148). TSLP appears to be also implicated in T2-low asthma pathobiology. In fact, this alarmin can induce dendritic cells to drive the commitment of naïve Th cells towards a Th17 immunophenotype (149).

Tezepelumab is an anti-TSLP fully human monoclonal antibody (Figure 1), which prevents TSLP binding to its receptor complex (150). Tezepelumab was firstly tested in patients with mild allergic asthma by Gauvreau et al., who noted that this anti-TSLP antibody reduced allergen-induced $\mathrm{FEV}_{1}$ decreases, as well as post-allergen increases in blood/sputum eosinophils and FeNO (151). A subsequent phase IIb trial was carried out by Corren et al., who showed that tezepelumab decreased the annualized asthma exacerbation rate by $60-70 \%$ and enhanced pre-bronchodilator $\mathrm{FEV}_{1}$, independently of blood eosinophil numbers (152). Furthermore, tezepelumab lowered the most relevant biomarkers of T2-high asthma, including IgE serum concentrations, blood eosinophil counts and FeNO levels (152). Ongoing phase II and III trials are evaluating the safety profile of tezepelumab, as well as its eventual efficacy in decreasing airway inflammation and OCS intake (142). So far, tezepelumab has not yet been investigated in regard to its potential therapeutic effects in patients with T2-low asthma.

IL-33 cooperates with TSLP in promoting type- 2 immune/ inflammatory responses (153). In particular, IL-33 induces airway hyperresponsiveness by stimulating IL-13 release from ILC2 and mast cells $(154,155)$. Several phase II trials are underway with the aim of evaluating some biologic drugs which target IL-33 or its ST2 receptor (142). In particular, it has been shown that the anti-IL-33 monoclonal antibody REGN3500 (Figure 1) was able to improve the control of severe asthma, but its therapeutic effects did not result to be better than those induced by dupilumab (142). Moreover, when tested in association with this IL-4/IL-13 dual receptor antagonist, the anti-asthma actions of such two biologicals were comparable to those exerted by dupilumab alone (142).

Although IL-25 plays a relevant pathogenic role in allergic inflammation, to our knowledge no anti-IL-25 monoclonal antibody is currently in clinical development for add-on treatment of severe asthma.

Another key mediator of type- 2 asthma is prostaglandin $\mathrm{D}_{2}$ $\left(\mathrm{PGD}_{2}\right)$, mainly produced by mast cells (156). PGD $\mathrm{P}_{2}$ exerts its pro-inflammatory actions via stimulation of CRTH2 (chemoattractant receptor-homologous molecule expressed on Th2 cells) receptor, expressed by Th2 lymphocytes, ILC2 and eosinophils (156). Binding of $\mathrm{PGD}_{2}$ to CRTH2 can be blocked by fevipiprant (Figure 1), a selective receptor antagonist which is not a monoclonal antibody, but rather a small compound used as an oral drug (156). Despite the partially promising results of some preliminary studies carried out in asthmatic patients, however fevipiprant seems to induce only a weak $\mathrm{FEV}_{1}$ increase, similar to the functional effect of the leukotriene 
TABLE 2 | New potential targets of emerging anti-asthma therapies.

\begin{tabular}{|c|c|c|c|}
\hline New potential targets & New potential drugs & Molecular mechanisms of action & Effects in the control of severe asthma \\
\hline TSLP & Tezepelumab & Prevention of TSLP binding to its receptor complex & $\begin{array}{l}\downarrow \text { Blood eosinophils } \\
\downarrow \text { FeNO } \\
\downarrow \text { Exacerbations } \\
\uparrow \text { FEV1 }\end{array}$ \\
\hline IL-33 & REGN3500 & Prevention of IL-33 binding to ST2 receptor & $\uparrow$ Quality of life and symptom control \\
\hline PGD2 & Fevipiprant & Selective antagonism of CRTH2 receptor & Weak FEV1 increase \\
\hline
\end{tabular}

receptor antagonist montelukast $(157,158)$. Further studies are thus needed, even if the therapeutic potential of fevipiprant for asthma therapy currently appears to be quite uncertain.

The molecular targets, mechanisms of action and therapeutic effects of the above mentioned drugs are summarized in Table 2.

With regard to the potential molecular targets of biological therapies for type 2-low neutrophilic asthma, the main focus of current studies is the pathogenic axis connecting IL-1 $\beta$, IL-23, and IL-17. In particular, the IL-1 receptor antagonist anakinra and the anti-IL-1 $\beta$ monoclonal antibody canakinumab are currently under clinical investigation in phase I/II trials enrolling patients with mild asthma $(159,160)$. In addition, further phase II studies are evaluating, in patients with severe type 2-low asthma, the efficacy and safety of the anti-IL-23 antibody risankizumab, as well as of an anti-IL-17A monoclonal antibody $(159,160)$. However, a previous trial carried out in moderate-to-severe asthmatics, aimed to investigate the effects of the anti-IL-17 receptor monoclonal antibody brodalumab, did not show any improvement in asthma symptom control and lung function (161).

\section{CONCLUSIONS}

Ongoing progress in our knowledge of the pathobiological mechanisms underlying the various cellular and molecular phenotypes of severe asthma has made it possible to unveil

\section{REFERENCES}

1. Holgate ST, Wenzel S, Postma DS, Weiss ST, Renz H, Sly PD. Asthma. Nat Rev Dis Primers (2015) 1:15025. doi: 10.1038/nrdp.2015.25

2. Papi A, Brightling C, Pedersen SE, Reddel HK. Asthma. Lancet (2018) 391:783-800. doi: 10.1016/S0140-6736(17)33311-1

3. Khalaf K, Paoletti G, Puggioni F, Racca F, De Luca E, Giorgis V, et al. Asthma from immune pathogenesis to precision medicine. Semin Immunol (2019) 46:101294. doi: 10.1016/j.smim.2019.101294

4. To T, Stanojevic S, Moores G, Gershon AS, Bateman ED, Cruz AA, et al. Global asthma prevalence in adults: findings from the cross-sectional world health survey. BMC Public Health (2012) 12:204. doi: 10.1186/1471-245812-204

5. Stern J, Pier J, Litonjua AA. Asthma epidemiology and risk factors. Semin Immunopathol (2020) 42:5-15. doi: 10.1007/s00281-020-00785-1

6. Heffler E, Blasi F, Latorre M, Menzella F, Paggiaro P, Pelaia G, et al. SANI network. The severe asthma network in Italy: findings and perspectives. J Allergy Clin Immunol Pract (2019) 7:1462-8. doi: 10.1016/j.jaip.2018.10.016

7. Chung KF, Wenzel SE, Brozek JL, Bush A, Castro M, Sterk PJ, et al. International ERS/ATS guidelines on definition, evaluation and treatment of severe asthma. Eur Respir J (2014) 43:343-73. doi: 10.1183/13993003.52020-2013 suitable targets for add-on biological therapies. Several approved anti-IgE, anti-IL-5, anti-IL-5 receptor, and anti-IL-4/IL-13 receptor monoclonal antibodies are currently prescribed by clinicians. These drugs are helping patients with severe, allergic or non-allergic eosinophilic T2-high asthma, to significantly improve symptom control, lung function and global health status, and especially to lessen their susceptibility to suffer from frequent and often serious disease exacerbations. Moreover, new promising monoclonal antibodies, mainly targeting the innate cytokines known as alarmins, are in advanced clinical development. However, patients with severe T2-low asthma are largely excluded from the therapeutic benefits achievable by people who experience T2-high severe disease. Therefore, in the coming years strong research efforts should be finalized to develop novel biological treatments for severe neutrophilic or paucigranulocytic asthma, thus hoping that patients expressing such uncontrolled phenotypes may pursue in the near future better health conditions than the current ones.

\section{AUTHOR CONTRIBUTIONS}

All authors contributed to elaborate the text and to draw the figure. All authors contributed to the article and approved the submitted version.

8. Siddiqui S, Denlinger LC, Fowler SJ, Akuthota P, Shaw DE, Heaney LG, et al. Unmet needs in severe asthma subtyping and precision medicine trials. Bridging clinical and patient perspectives. Am J Respir Crit Care Med (2019) 199:823-9. doi: 10.1164/rccm.201809-1817PP

9. Pelaia G, Vatrella A, Maselli R. The potential of biologics for the treatment of asthma. Nat Rev Drug Discovery (2012) 11:958-72. doi: 10.1038/nrd3792

10. Peters MC, Wenzel SE. Intersection of biology and therapeutics: type 2 targeted therapeutics for adult asthma. Lancet (2020) 395:371-83. doi: 10.1016/S0140-6736(19)33005-3

11. Chupp GL, Kaur R, Mainardi A. New therapies for emerging endotypes of asthma. Annu Rev Med (2020) 71:25.1-25.14. doi: 10.1146/annurev-med041818-020630

12. Al-Sajee D, Oliveria JP, Sehmi R, Gauvreau GM. Antialarmins for treatment of asthma. Curr Opin Pulm Med (2018) 24:32-41. doi: 10.1097/ MCP.0000000000000443

13. Nakajima S, Kabata H, Kabashima K, Asano K. Anti-TSLP antibodies: targeting a master regulator of type 2 immune responses. Allergol Int (2020) 69:197-203. doi: 10.1016/j.alit.2020.01.001

14. Pepper AN, Renz H, Casale TB, Garn H. Biologic therapy and novel molecular targets of severe asthma. J Allergy Clin Immunol Pract (2017) 5:909-16. doi: 10.1016/j.jaip.2017.04.038 
15. Krings JG, McGregor MC, Bacharier LB, Castro M. Biologics for severe asthma: treatment-specific effects are important in choosing a specific agent. J Allergy Clin Immunol Pract (2019) 7:1379-92. doi: 10.1016/j.jaip.2019.03.008

16. Kuruvilla ME, Lee FE, Lee GB. Understanding asthma phenotypes, endotypes, and mechanisms of disease. Clin Rev Allergy Immunol (2019) 56:219-33. doi: 10.1007/s12016-018-8712-1

17. Lambrecht $\mathrm{BN}$, Hammad H, Fahy JV. The cytokines of asthma. Immunity (2019) 50:975-91. doi: 10.1016/j.immuni.2019.03.018

18. Pelaia G, Vatrella A, Busceti MT, Gallelli L, Calabrese C, Terracciano R, et al. Cellular mechanisms underlying eosinophilic and neutrophilic airway nflammation in asthma. Mediators Inflamm (2015) 2015:879783. doi: $10.1155 / 2015 / 879783$

19. Wenzel SE. Complex phenotypes in asthma: current definitions. Pulm Pharmacol Ther (2013) 26:710-15. doi: 10.1016/j.pupt.2013.07.003

20. Ray A, Oriss TB, Wenzel SE. Emerging molecular phenotypes of asthma. Am J Physiol Lung Cell Mol Physiol (2015) 308:L130-40. doi: 10.1152/ ajplung.00070.2014

21. Schoettler N, Strek ME. Recent advances in severe asthma: from phenotypes to personalized medicine. Chest (2020) 157:516-28. doi: 10.1016/ j.chest.2019.10.009

22. McDowell PJ, Heaney LG. Different endotypes and phenotypes drive the heterogeneity in severe asthma. Allergy (2020) 75:302-10. doi: 10.1111/ all.13966

23. Bousquet J, Chanez P, Lacoste JY, Barnéon G, Ghavanian N, Enander I, et al. Eosinophilic inflammation in asthma. N Engl J Med (1990) 323:1033-9. doi: 10.1056/NEJM199010113231505

24. Schleich F, Brusselle G, Louis R, Vandenplas O, Michils A, Pilette C, et al. Heterogeneity of phenotypes in severe asthma. The Belgian severe asthma registry (BSAR). Respir Med (2014) 108:1723-32. doi: 10.1016/ j.rmed.2014.10.007

25. Huber KL, Koessler K. The pathology of fatal asthma. Arch Intern Med (1922) 30:689-760. doi: 10.1001/archinte.1922.00110120002001

26. Houston JC, De Navasquez S. Trounce JR. A clinical and pathological study of fatal cases of status asthmaticus. Thorax (1953) 8:207-13. doi: 10.1136/thx.8.3.207

27. Nelson RK, Bush A, Stokes J, Nair P, Akuthota P. Eosinophilic asthma. J Allergy Clin Immunol (2020) 8:465-73. doi: 10.1016/j.jaip.2019.11.024

28. Lambrecht BN, Hammad H. The immunology of asthma. Nat Immunol (2015) 16:45-54. doi: 10.1038/ni.3049

29. Kaiko GE, Horvat JC, Beagley KW, Hansbro PM. Immunological decisionmaking: how does the immune system decide to mount a helper T-cell response? Immunology (2008) 123:326-38. doi: 10.1111/j.13652567.2007.02719.x

30. Kallinich T, Beier KC, Wahn U, Stock P, Hamelmann E. T-cell costimulatory molecules: their role in allergic immune reactions. Eur Respir $J$ (2007) 29:1246-55. doi: 10.1183/09031936.00094306

31. Froidure A, Mouthuy J, Durham SR, Chanez P, Sibille Y, Pilette C. Asthma phenotypes and IgE responses. Eur Respir J (2016) 47:304-19. doi: 10.1183/ 13993003.01824-2014

32. Gould HJ, Sutton BJ. IgE in allergy and asthma today. Nat Rev Immunol (2008) 8:205-17. doi: $10.1038 /$ nri2273

33. Hentges F, Leonard C, Arumugam K, Hilger C. Immune responses to inhalant mammalian allergens. Front Immunol (2014) 5:234. doi: 10.3389/ fimmu.2014.00234

34. Dullaers M, De Bruyne R, Ramadani F, Gould HJ, Gevaert P, Lambrecht BN. The who, where and when of IgE in allergic airway disease. J Allergy Clin Immunol (2012) 129:635-45. doi: 10.1016/j.jaci.2011.10.029

35. Hammad H, Lambrecht BN. Barrier epithelial cells and the control of type 2 immunity. Immunity (2015) 43:29-40. doi: 10.1016/j.immuni.2015.07.007

36. Morita $\mathrm{H}$, Moro K, Koyasu S. Innate lymphoid cells in allergic and nonallergic inflammation. J Allergy Clin Immunol (2016) 138:1253-64. doi: 10.1016/j.jaci.2016.09.011

37. Cosmi L, Annunziato F. ILC2 are the earliest recruiters of eosinophils in lungs of allergic asthmatic patients. Am J Respir Crit Care Med (2017) 196:666-8. doi: 10.1164/rccm.201704-0799ED

38. Pattarini L, Trichot C, Bogiatzi S, Grandclaudon M, Meller S, Keuylian Z, et al. TSLP-activated dendritic cells induce human T follicular helper cell differentiation through OX40-ligand. J Exp Med (2017) 214:1529-46. doi: 10.1084/jem.20150402
39. Barnes PJ. The cytokine network in asthma and chronic obstructive pulmonary disease. J Clin Invest (2008) 118:3546-56. doi: 10.1172/JCI36130

40. Pelaia C, Paoletti G, Puggioni F, Racca F, Pelaia G, Canonica GW, et al. Interleukin-5 in the pathophysiology of severe asthma. Front Physiol (2019) 10:1514. doi: 10.3389/fphys.2019.01514

41. Brusselle GG, Maes T, Bracke KR. Eosinophilic airway inflammation in non allergic asthma. Nat Med (2013) 19:977-9. doi: 10.1038/nm.3300

42. Walker JA, Barlow JL, McKenzie AM. Innate lymphoid cells: how did we miss them? Nat Rev Immunol (2013) 13:75-87. doi: 10.1038/nri3349

43. Wood LJ, Sehmi R, Dorman S, Hamid Q, Tulic MK, Watson RM, et al. Allergen-induced increases in bone marrow $\mathrm{T}$ lymphocytes and interleukin5 expression in subjects with asthma. Am J Respir Crit Care Med (2002) 166:883-9. doi: 10.1164/rccm.2108015

44. Dorman SC, Efthimiadis A, Babirad I, Watson RM, Denburg JA, Hargreave $\mathrm{FE}$, et al. Sputum CD34+ IL-5R $\alpha+$ cells increase after allergen: evidence for in situ eosinophilopoiesis. Am J Respir Crit Care Med (2004) 169:573-7. doi: 10.1164/rccm.200307-1004OC

45. Bhalla A, Mukherjee M, Nair P. Airway eosinophilopoietic and autoimmune mechanisms of eosinophilia in severe asthma. Immunol. Allergy Clin N Am (2018) 38:639-54. doi: 10.1016/j.iac.2018.06.003

46. Greenfeder S, Umland SP, Cuss FM, Chapman RW, Egan RW. Th2 cytokines and asthma. The role of interleukin-5 in allergic eosinophilic disease. Respir Res (2001) 2:71-9. doi: 10.1186/rr41

47. Xu J, Jiang F, Nayeri F, Zetterstrom O. Apoptotic eosinophils in sputum from asthmatic patients correlate negatively with levels of IL-5 and eotaxin. Respir Med (2007) 101:1447-54. doi: 10.1016/j.rmed.2007.01.026

48. Ilmarinen P, Moilanen E, Kankaanranta H. Regulation of spontaneous eosinophil apoptosis - a neglected area of importance. J Cell Death (2014) 7:1-9. doi: 10.4137/JCD.S13588

49. Fulkerson PC, Rothenberg ME. Targeting eosinophils in allergy, inflammation and beyond. Nat Rev Drug Discovery (2013) 12:117-29. doi: $10.1038 / \mathrm{nrd} 3838$

50. Johansson MV. Eosinophil activation status in separate compartments and association with asthma. Front Med (2017) 4:75. doi: 10.3389/fmed.2017.00075

51. Wenzel S. Severe asthma in adults. Am J Respir Crit Care Med (2005) 172:149-60. doi: 10.1164/rccm.200409-1181PP

52. Makinde T, Murphy RF, Agrawall DK. The regulatory role of TGF- $\beta$ in airway remodeling in asthma. Immunol Cell Biol (2007) 85:348-56. doi: 10.1038/sj.icb.7100044

53. Ray A, Kolls JK. Neutrophilic inflammation in asthma and association with disease severity. Trends Immunol (2017) 38:942-54. doi: 10.1016/j.it.2017.07.003

54. Aujla SJ, Alcorn JF. $\mathrm{T}_{\mathrm{H}} 17$ cells in asthma and inflammation. Biochim Biophys Acta (2011) 1810:1066-79. doi: 10.1016/j.bbagen.2011.02.002

55. Newcomb DC, Peebles RSJr. Th17-mediated inflammation in asthma. Curr Opin Immunol (2013) 25:755-60. doi: 10.1016/j.coi.2013.08.002

56. Cosmi L, Liotta F, Maggi S, Romagnani S, Annunziato F. Th17 cells: new players in asthma pathogenesis. Allergy (2011) 66:989-98. doi: 10.1111/ j.1398-9995.2011.02576.x

57. Al-Ramli W, Prefontaine D, Chouiali F, Martin JG, Olivenstein R, Lemière C, et al. $\mathrm{T}_{\mathrm{H}} 17$-associated cytokines (IL-17A and IL-17F) in severe asthma. J Allergy Clin Immunol (2009) 123:1185-7. doi: 10.1016/j.jaci.2009.02.024

58. Huang G, Wang $Y$, Chi H. Regulation of $\mathrm{T}_{\mathrm{H}} 17$ cell differentiation by innate immune signals. Cell Mol Immunol (2012) 9:287-95. doi: 10.1038/ cmi.2012.10

59. Vroman H, van den Blink B, Kool M. Mode of dendritic cell activation: the decisive hand in Th2/Th17 cell differentiation. Implications in asthma severity? Immunobiology (2015) 220:254-61. doi: 10.1016/j.imbio.2014.09.016

60. Zhou L, Ivanov II, Spolski R, Min R, Shenderov K, Egawa T, et al. IL-6 programs $\mathrm{T}(\mathrm{H})-17$ cell differentiation by promoting sequential engagement of the IL-21 and IL-23 pathways. Nat Immunol (2007) 8:967-74. doi: $10.1038 /$ ni 1488

61. Ramakrishnan RK, Heialy SA, Hamid Q. Role of IL-17 in asthma pathogenesis and its implications for the clinic. Expert Rev Respir Med (2019) 13:1057-68. doi: 10.1080/17476348.2019.1666002

62. McGeachy MJ, Chen Y, Tato CM, Laurence A, Joyce-Shaikh B, Blumenschein WM, et al. The interleukin 23 receptor is essential for the terminal differentiation of interleukin 17-producing effector T helper cells in vivo. Nat Immunol (2009) 10:314-24. doi: 10.1038/ni.1698 
63. Thomson NC, Chaudhuri R, Livingston E. Asthma and cigarette smoking. Eur Respir J (2004) 24:822-33. doi: 10.1183/09031936.04.00039004

64. Polosa R, Thomson NC. Smoking and asthma: dangerous liaisons. Eur Respir J (2013) 41:716-26. doi: 10.1183/09031936.00073312

65. Brusselle GG, Provoost S, Bracke KR, Kuchmiy A, Lamkanfi M. Inflammasomes in respiratory disease: from bench to bedside. Chest (2014) 145:1121-33. doi: 10.1378/chest.13-1885

66. Lee TH, Song HJ, Park CS. Role of inflammasome activation in development and exacerbation of asthma. Asia Pac Allergy (2014) 4:187-96. doi: 10.5415/ apallergy.2014.4.4.187

67. Kim HY, Lee HJ, Chang YJ, Pichavant M, Shore SA, Fitzgerald KA, et al. Interleukin-17-producing innate lymphoid cells and the NLRP3 inflammasome facilitate obesity-associated airway hyper-reactivity. Nat Med (2014) 20:54-61. doi: 10.1038/nm.3423

68. Krishnamoorthy N, Douda DN, Bruggermann TR, Ricklefs I, Duvall MG, Abdulnour REE, et al. Neutrophil cytoplasts induce TH17 differentiation toward neutrophilia in severe asthma. Sci Immunol (2018) 3:eaao4747. doi: 10.1126/sciimmunol.aao4747

69. Uddin M, Watz H, Malmgren A, Pedersen F. NETopathic inflammation in chronic obstructive pulmonary disease and severe asthma. Front Immunol (2019) 10:47. doi: 10.3389/fimmu.2019.00047

70. Twaddell SH, Baines KJ, Grainge C, Gibson PG. The emerging role of neutrophil extracellular traps in respiratory disease. Chest (2019) 156:77482. doi: 10.1016/j.chest.2019.06.012

71. Manni ML, Robinson KM, Alcorn JF. A tale of two cytokines: IL-17 and IL22 in asthma and infection. Expert Rev Respir Med (2014) 8:25-42. doi: 10.1586/17476348.2014.854167

72. Yu S, Kim HY, Chang YJ, DeKruiff RH, Umetsu DT. Innate lymphoid cells and asthma. J Allergy Clin Immunol (2014) 133:943-50. doi: 10.1016/ j.jaci.2014.02.015

73. Wu Y, Yue J, Wu J, Zhou W, Li D, Ding K, et al. Obesity may provide proILC3 development inflammatory environment in asthmatic children. J Immunol Res (2018) 2018:1628620. doi: 10.1155/2018/1628620

74. Durrant DM, Metzger DW. Emerging roles of T helper subsets in the pathogenesis of asthma. Immunol Investig (2010) 39:526-49. doi: 10.3109/ 08820131003615498

75. Wang YH, Wills-Karp MS. The potential role of interleukin-17 in severe asthma. Curr Allergy Asthma Rep (2011) 11:388-94. doi: 10.1007/s11882011-0210-y

76. Halwani R, Al-Muhsen S, Hamid Q. T helper 17 cells in airway diseases: from laboratory bench to bedside. Chest (2013) 143:494-501. doi: 10.1378/ chest.12-0598

77. Saffar AS, Ashdown H, Gounni AS. The molecular mechanisms of glucocorticoids-mediated neutrophil survival. Curr Drug Targets (2011) 12:556-62. doi: 10.2174/138945011794751555

78. Kadowaki N. Dendritic cells: a conductor of T cell differentiation. Allergol Int (2007) 56:193-9. doi: 10.2332/allergolint.R-07-146

79. Berry MA, Hargadon B, Shelley M, Parker D, Shaw DE, Green RH, et al. Evidence of a role of tumor necrosis factor $\alpha$ in refractory asthma. $N$ Engl $J$ Med (2006) 354:697-708. doi: 10.1056/NEJMoa050580

80. Cosmi L, Maggi L, Santarlasci V, Capone M, Cardilicchia E, Frosati F, et al. Identification of a novel subset of human circulating memory $\mathrm{CD} 4^{+} \mathrm{T}$ cells that produce both IL-17A and IL-4. J Allergy Clin Immunol (2010) 125:22230. doi: $10.1016 /$ j.jaci.2009.10.012

81. Irvin C, Zafar I, Good J, Rollins D, Christianson C, Gorska MM, et al. Increased frequency of dual-positive $\mathrm{T}_{\mathrm{H}} 2 / \mathrm{T}_{\mathrm{H}} 17$ cells in bronchoalveolar lavage fluid characterizes a population of patients with severe asthma. J Allergy Clin Immunol (2014) 134:1175-86. doi: 10.1016/j.jaci.2014.05.038

82. Wang YH, Voo KS, Liu B, Chen CY, Uygungil B, Spoede W, et al. A novel subset of $\mathrm{CD} 4(+) \mathrm{T}(\mathrm{H}) 2$ memory effector cells that produce inflammatory IL-17 cytokine and promote the exacerbation of chronic allergic asthma. J Exp Med (2010) 207:2479-91. doi: 10.1084/jem.20101376

83. Bhakta NR, Erle DJ. IL-17 and " $\mathrm{T}_{\mathrm{H}} 2$-high" asthma: adding fuel to the fire? J Allergy Clin Immunol (2014) 134:1187-8. doi: 10.1016/j.jaci.2014.07.034

84. Jenkins HA, Cherniack R, Szefler SJ, Covar R, Gelfand EW, Spahn JD. A comparison of the clinical characteristics of children and adults with severe asthma. Chest (2003) 124:1318-24. doi: 10.1378/chest.124.4.1318
85. Wenzel SE. Asthma: defining of the persistent adult phenotypes. Lancet (2006) 368:804-13. doi: 10.1016/S0140-6736(06)69290-8

86. Tliba O, Panettieri RAJr. Paucigranulocytic asthma: uncoupling of airway obstruction from inflammation. J Allergy Clin Immunol (2019) 143:1287-94. doi: 10.1016/j.jaci.2018.06.008

87. Pelaia G, Vatrella A, Busceti MT, Gallelli L, Terracciano R, Maselli R. AntiIgE therapy with omalizumab for severe asthma: current concepts and potential developments. Curr Drug Targets (2015) 16:171-8. doi: 10.2174/ 1389450116666141219122157

88. Pelaia G, Canonica GW, Matucci A, Paolini R, Triggiani M, Paggiaro P. Targeted therapy in severe asthma today: focus on immunoglobulin E. Drug Des Devel Ther (2017) 11:1979-87. doi: 10.2147/DDDT.S130743

89. Rodrigo GJ, Neffen H, Castro-Rodriguez JA. Efficacy and safety of subcutaneous omalizumab vs placebo as add-on therapy to corticosteroids for children and adults with asthma: a systematic review. Chest (2011) 139:28-35. doi: 10.1378/chest.10-1194

90. Normansell R, Walker S, Milan SJ, Walters EH, Nair P. Omalizumab for asthma in adults and children. Cochrane Database Syst Rev (2014) 1: CD003559. doi: 10.1002/14651858.CD003559.pub4

91. Pelaia C, Calabrese C, Terracciano R, de Blasio F, Vatrella A, Pelaia G. Omalizumab, the first available antibody for biological treatment of asthma: more than a decade of real life effectiveness. Ther Adv Respir Dis (2018) 12. 1753466618810192. doi: 10.1177/1753466618810192

92. Cabrejos S, Moreira A, Ramirez A, Quirce S, Campos GS, Davila I, et al. FENOMA study: achieving full control in patients with severe allergic asthma. J Asthma Allergy (2020) 13:159-66. doi: 10.2147/JAA.S246902

93. Pelaia G, Gallelli L, Romeo P, Renda T, Busceti MT, Proietto A, et al. Omalizumab decreases exacerbation frequency, oral intake of corticosteroids and peripheral blood eosinophils in atopic patients with uncontrolled asthma. Int J Clin Pharmacol Ther (2011) 49:713-21. doi: 10.5414/CP201586

94. Pelaia C, Calabrese C, Barbuto S, Busceti MT, Preianò M, Gallelli L, et al. Omalizumab lowers asthma exacerbations, oral corticosteroid intake and blood eosinophils: results of a 5-year single centre observational study. Pulm Pharmacol Ther (2019) 54:25-30. doi: 10.1016/j.pupt.2018.11.002

95. Pace E, Ferraro M, Bruno A, Chiappara G, Bousquet J, Gjomarkaj M, et al. Clinical benefits of 7 years of treatment with omalizumab in severe uncontrolled asthmatics. J Asthma (2011) 48:387-92. doi: 10.3109/ 02770903.2011.561512

96. Menzella F, Galeone C, Formisano D, Castagnetti C, Ruggiero P, Simonazzi A, et al. Real life efficacy of omalizumab after 9 years of follow-up. Allergy Asthma Immunol Res (2017) 9:368-72. doi: 10.4168/aair.2017.9.4.368

97. Tiotiu A, Oster JP, Roux PR, Nguyen Thi PL, Peiffer G, Bonniaud P, et al. Effectiveness of omalizumab in severe allergic asthma and nasal polyposis: a real-life study. J Invest Allergol Clin Immunol (2020) 30:49-57. doi: 10.18176/jiaci.0391

98. Campisi R, Crimi C, Intravaia R, Strano S, Noto A, Foschino MP, et al. Adherence to omalizumab: a multi center "real-world" study. World Allergy Organ J (2020) 13:100103. doi: 10.1016/j.waojou.2020.100103

99. Di Bona D, Fiorino I, Taurino M, Frisenda F, Minenna E, Pasculli C, et al. Long-term "real life" safety of omalizumab in patients with severe uncontrolled asthma: a nine-year study. Respir Med (2017) 130:55-60. doi: 10.1016/j.rmed.2017.07.013

100. Pelaia C, Vatrella A, Busceti MT, Gallelli L, Terracciano R, Savino R, et al. Severe eosinophilic asthma: from the pathogenic role of interleukin-5 to the therapeutic action of mepolizumab. Drug Des Devel Ther (2017) 11:3137-44. doi: 10.2147/DDDT.S150656

101. Haldar P, Brightling CE, Hargadon B, Gupta S, Monteiro W, Sousa A, et al. Mepolizumab and exacerbations of refractory eosinophilic asthma. New Engl J Med (2009) 360:973-84. doi: 10.1056/NEJMoa0808991

102. Nair P, Pizzichini MM, Kjarsgaard M, Inman MD, Efthimiadis A, Pizzichini E, et al. Mepolizumab for prednisone-dependent asthma with sputum eosinophilia. New Engl J Med (2009) 360:985-93. doi: 10.1056/ NEJMoa0805435

103. Pavord ID, Korn S, Howarth P, Bleecker ER, Buhl R, Keene ON, et al. Mepolizumab for severe eosinophilic asthma (DREAM): a multicentre, double-blind, placebo-controlled trial. Lancet (2012) 380:651-9. doi: 10.1016/S0140-6736(12)60988-X 
104. Ortega HG, Liu MC, Pavord ID, Brusselle GG, FitzGerald JM, Chetta A, et al. Mepolizumab treatment in patients with severe eosinophilic asthma. $N$ Engl J Med (2014) 371:1198-207. doi: 10.1056/NEJMoa1403290

105. Bel EH, Wenzel SE, Thompson PJ, Prazma CM, Keene ON, Yancey SW, et al. Oral glucocorticoid-sparing effect of mepolizumab in eosinophilic asthma. $N$ Engl J Med (2014) 371:1189-97. doi: 10.1056/NEJMoa1403291

106. Chupp GL, Bradford ES, Albers FC, Bratton DJ, Wang-Jairaj J, Nelsen LM, et al. Efficacy of mepolizumab add-on therapy on health-related quality of life and markers of asthma control in severe eosinophilic asthma (MUSCA): a randomized, double-blind, placebo-controlled, parallel-group, multicenter, phase 3b trial. Lancet Respir Med (2017) 5:390-400. doi: 10.1016/S2213-2600 (17)30125-X

107. Bagnasco D, Milanese M, Rolla G, Lombardi C, Bucca C, Heffler E, et al. The North-Western Italian experience with anti IL-5 therapy and comparison with regulatory trials. World Allergy Organ J (2018) 11:34. doi: 10.1186/ s40413-018-0210-7

108. Pelaia C, Busceti MT, Solinas S, Terracciano R, Pelaia G. Real-life evaluation of the clinical, functional, and hematological effects of mepolizumab in patients with severe eosinophilic asthma: results of a single-centre observational study. Pulm Pharmacol Ther (2018) 53:1-5. doi: 10.1016/j.pupt.2018.09.006

109. Pelaia C, Crimi C, Pelaia G, Nolasco S, Campisi R, Heffler E, et al. Real-life evaluation of mepolizumab efficacy in patients with severe eosinophilic asthma, according to atopic trait and allergic phenotype. Clin Exp Allergy (2020) 50:780-8. doi: 10.1111/cea.13613

110. Chapman KR, Albers FC, Chipps B, Munoz X, Devouassoux G, Bergna M, et al. The clinical benefit of mepolizumab replacing omalizumab in uncontrolled severe eosinophilic asthma. Allergy (2019) 74:1716-26. doi: 10.1111/all.13850

111. Carpagnano GE, Pelaia C, D’Amato M, Crimi N, Scichilone N, Scioscia G, et al. Switching from omalizumab to mepolizumab: real-life experience from Southern Italy. Ther Adv Respir Dis (2020) 14. 1753466620929231. doi: $10.1177 / 1753466620929231$

112. Sposato B, Camiciottoli G, Bacci E, Scalese M, Carpagnano GE, Pelaia C, et al. Mepolizumab effectiveness on small airway obstruction, corticosteroid sparing and maintenance therapy step-down in real life. Pulm Pharmacol Ther (2020) 61:101899. doi: 10.1016/j.pupt.2020.101899

113. Bachert C, Sousa AR, Lund VJ, Scadding GK, Gevaert P, Nasser S, et al. Reduced need for surgery in severe nasal polyposis with mepolizumab: randomized trial. J Allergy Clin Immunol (2017) 140:1024-31. doi: 10.1016/ j.jaci.2017.05.044

114. Pelaia G, Vatrella A, Busceti MT, Gallelli L, Preianò M, Lombardo N, et al. Role of biologics in severe eosinophilic asthma: focus on reslizumab. Ther Clin Risk Manage (2016) 12:1075-82. doi: 10.2147/TCRM.S111862

115. Varricchi G, Senna G, Loffredo S, Bagnasco D, Ferrando M, Canonica GW. Reslizumab and eosinophilic asthma: one step closer to precision medicine? Front Immunol (2017) 8:242. doi: 10.3389/fimmu.2017.00242

116. Kips JC, O'Connor BJ, Langley SJ, Woodcock A, Kerstjens HA, Postma DS, et al. Effects of SCH55700, a humanized anti-human interleukin-5 antibody, in severe persistent asthma: a pilot study. Am J Respir Crit Care Med (2003) 167:1655-9. doi: 10.1164/rccm.200206-525OC

117. Castro M, Mathur S, Hargreave F, Boulet LP, Xie F, Young J, et al. Reslizumab for poorly controlled, eosinophilic asthma: a randomized, placebo-controlled study. Am J Respir Crit Care Med (2011) 184:1125-32. doi: 10.1164/rccm.201103-0396OC

118. Castro M, Zangrilli J, Wechsler ME, Bateman ED, Brusselle GG, Bardin P, et al. Reslizumab for inadequately controlled asthma with elevated blood eosinophil counts: results from two multicentre, parallel, double-blind, randomised, placebo-controlled, phase 3 trials. Lancet Respir Med (2015) 3:355-66. doi: 10.1016/S2213-2600(15)00042-9

119. Brusselle G, Germinaro M, Weiss S, Zangrilli J. Reslizumab in patients with inadequately controlled late-onset asthma and elevated blood eosinophils. Pulm Pharmacol Ther (2017) 43:39-45. doi: 10.1016/j.pupt.2017.01.011

120. Bjermer L, Lemiere C, Maspero J, Weiss S, Zangrilli J, Germinaro M. Reslizumab for inadequately controlled asthma with elevated blood eosinophil levels: a randomized phase 3 study. Chest (2016) 150:789-98. doi: 10.1016/j.chest.2016.03.032

121. Pelaia C, Vatrella A, Bruni A, Terracciano R, Pelaia G. Benralizumab in the treatment of severe asthma: design, development and potential place in therapy. Drug Des Devel Ther (2018) 12:619-28. doi: 10.2147/ DDDT.S155307

122. Pelaia C, Calabrese C, Vatrella A, Busceti MT, Garofalo E, Lombardo N, et al. Benralizumab: from the basic mechanism of action to the potential use in the biological therapy of severe eosinophilic asthma. BioMed Res Int (2018) 2018:4839230. doi: $10.1155 / 2018 / 4839230$

123. Bleecker ER, FitzGerald JM, Chanez P, Papi A, Weinstein SF, Barker P, et al. Efficacy and safety of benralizumab for patients with severe asthma uncontrolled with high-dosage inhaled corticosteroids and long-acting $\beta_{2^{-}}$ agonists (SIROCCO): a randomized, multicentre, placebo-controlled phase 3 trial. Lancet (2016) 388:2115-27. doi: 10.1016/S0140-6736(16)31324-1

124. FitzGerald JM, Bleecker ER, Nair P, Korn S, Ohta K, Lommatzsch M, et al. Benralizumab, an anti-interleukin-5 receptor $\alpha$ monoclonal antibody, as add-on treatment for patients with severe, uncontrolled eosinophilic asthma (CALIMA): a randomised, double-blind, placebo-controlled phase 3 trial. Lancet (2016) 388:2128-41. doi: 10.1016/S0140-6736(16)31322-8

125. Chipps BE, Newbold P, Hirsch I, Trudo F, Goldman M. Benralizumab efficacy by atopy status and serum immunoglobulin $\mathrm{E}$ for patients with severe, uncontrolled asthma. Ann Allergy Asthma Immunol (2018) 120:50411. doi: 10.1016/j.anai.2018.01.030

126. Ferguson GT, FitzGerald JM, Bleecker ER, Laviolette M, Bernstein D, LaForce $\mathrm{C}$, et al. Benralizumab for patients with mild to moderate persistent asthma (BISE): a randomised, double-blind, placebo-controlled phase 3 trial. Lancet Respir Med (2017) 5:568-76. doi: 10.1016/S2213-2600 (17) $30190-\mathrm{X}$

127. Nair P, Wenzel S, Rabe KF, Bourdin A, Lugogo NL, Kuna P, et al. Oral glucocorticoid-sparing effect of benralizumab in severe asthma. N Engl J Med (2017) 376:2448-58. doi: 10.1056/NEJMoa1703501

128. Busse ER, Bleecker JM, FitzGerald GT, Ferguson GT, Barker P, Sproule S, et al. Long-term safety and efficacy of benralizumab in patients with severe, uncontrolled asthma: 1-year results from the BORA phase 3 extension trial. Lancet Respir Med (2019) 7:46-59. doi: 10.1016/S2213-2600(18)30406-5

129. Pelaia C, Busceti MT, Vatrella A, Rago GF, Crimi C, Terracciano R, et al. Real-life rapidity of benralizumab effects in patients with severe allergic asthma: assessment of blood eosinophils, symptom control, lung function and oral corticosteroid intake after the first drug dose. Pulm Pharmacol Ther (2019) 58:101830. doi: 10.1016/j.pupt.2019.101830

130. Pelaia C, Busceti MT, Crimi C, Carpagnano GE, Lombardo N, Terracciano R, et al. Real-life effects of benralizumab on exacerbation number and lung hyperinflation in atopic patients with severe eosinophilic asthma. BioMed Pharmacother (2020) 129:110444. doi: 10.1016/j.biopha.2020.110444

131. Pelaia C, Busceti MT, Vatrella A, Ciriolo M, Garofalo E, Crimi C, et al. Effects of the first three doses of benralizumab on symptom control, lung function, blood eosinophils, oral corticosteroid intake, and nasal polyps in a patient with severe allergic asthma. SAGE Open Med Case Rep (2020) 8. 2050313X20906963. doi: 10.1177/2050313X20906963

132. Lombardo N, Pelaia C, Ciriolo M, Della Corte M, Piazzetta G, Lobello N, et al. Real-life effects of benralizumab on allergic chronic rhinosinusitis and nasal polyposis associated with severe asthma. Int J Immunopathol Pharmacol (2020) 34. 2058738420950851. doi: 10.1177/2058738420950851

133. Pelaia C, Vatrella A, Gallelli L, Terracciano R, Navalesi P, Maselli R, et al. Dupilumab for the treatment of asthma. Expert Opin Biol Ther (2017) 17:1565-72. doi: 10.1080/14712598.2017.1387245

134. Harb H, Chatila TA. Mechanisms of dupilumab. Clin Exp Allergy (2020) 50:5-14. doi: 10.1111/cea.13491

135. Wenzel S, Ford L, Pearlman D, Spector S, Sher L, Skobieranda F, et al. Dupilumab in persistent asthma with elevated eosinophil levels. N Engl J Med (2013) 368:2455-66. doi: 10.1056/NEJMoa1304048

136. Wenzel S, Castro M, Corren J, Maspero J, Wang L, Zhang B, et al. Dupilumab efficacy and safety in adults with uncontrolled persistent asthma despite use of medium-to-high-dose inhaled corticosteroids plus a long-acting $\beta_{2}$ agonist: a randomised double-blind placebo-controlled pivotal phase $2 b$ dose-ranging trial. Lancet (2016) 388:31-44. doi: 10.1016/S0140-6736(16) 30307-5

137. Castro M, Corren J, Pavord ID, Maspero J, Wenzel S, Rabe K, et al. Dupilumab efficacy and safety in moderate-to-severe uncontrolled asthma. N Engl J Med (2018) 378:2486-96. doi: 10.1056/NEJMoa1804092 
138. Corren J, Castro M, O'Riordan T, Hanania NA, Pavord ID, Quirce S, et al. Dupilumab efficacy in patients with uncontrolled, moderate-to-severe allergic asthma. J Allergy Clin Immunol Pract (2020) 8:516-26. doi: 10.1016/j.jaip.2019.08.050

139. Rabe KF, Nair P, Brusselle G, Maspero JF, Castro M, Sher L, et al. Efficacy and safety of dupilumab in glucocorticoid-dependent severe asthma. $\mathrm{N} \mathrm{Engl} \mathrm{J}$ Med (2018) 378:2475-85. doi: 10.1056/NEJMoa1804093

140. Seegraber M, Srour J, Walter A, Knop M, Wollenberg A. Dupilumab for treatment of atopic dermatitis. Expert Rev Clin Pharmacol (2018) 11:467-74. doi: 10.1080/17512433.2018.1449642

141. Bachert C, Hellings PW, Mullol J, Hamilos DL, Gevaert P, Naclerio RM, et al. Dupilumab improves health-related quality of life in patients with chronic rhinosinusitis with nasal polyposis. Allergy (2020) 75:148-57. doi: 10.1111/ all.13984

142. Porsbjerg CM, Sverrild A, Lloyd CM, Menzies-Gow AN, Bel EH. Anti-alarmins in asthma: targeting the airway epithelium with next-generation biologics. Eur Respir J (2020) 56. doi: 10.1183/13993003.00260-2020. in press.

143. Matera MG, Rogliani P, Calzetta L, Cazzola M. TSLP inhibitors for asthma: current status and future prospects. Drugs (2020) 80:449-58. doi: 10.1007/ s40265-020-01273-4

144. Ito T, Wang YH, Duramad O, Hori T, Delespesse GJ, Watanabe L, et al. TSLP-activated dendritic cells induce an inflammatory T helper type 2 cell response through OX40 ligand. J Exp Med (2005) 202:1213-23. doi: 10.1084/ jem. 20051135

145. Soumelis V, Reche PA, Kanzler H, Yuan W, Edward G, Homey B, et al. Human epithelial cells trigger dendritic cell mediated allergic inflammation by producing TSLP. Nat Immunol (2002) 3:673-80. doi: 10.1038/ni805

146. Allakhverdi Z, Comeau MR, Jessup HK, Yoon BR, Brewer A, Chartier S, et al. Thymic stromal lymphopoietin is released by human epithelial cells in response to microbes, trauma, or inflammation and potently activates mast cells. J Exp Med (2007) 204:253-8. doi: 10.1084/jem.20062211

147. Camelo A, Rosignoli G, Ohne Y, Stewart RA, Overed-Sayer C, Sleeman MA, et al. IL-33, IL-25, and TSLP induce a distinct phenotypic and activation profile in human type 2 innate lymphoid cells. Blood Adv (2017) 1:577-89. doi: 10.1182/bloodadvances.2016002352

148. Liu S, Verma M, Michalec L, Liu W, Sripada A, Rollins D, et al. Steroid resistance of airway type 2 innate lymphoid cells from patients with severe asthma: the role of thymic stromal lymphopoietin. J Allergy Clin Immunol (2018) 141:257-68. doi: 10.1016/j.jaci.2017.03.032

149. Tanaka J, Watanabe N, Kido M, Saga K, Akamatsu T, Nishio A, et al. and TLR3 ligands promote differentiation of Th17 cells with a central memory phenotype under Th2-polarizing conditions. Clin Exp Allergy (2009) 39:89100. doi: 10.1111/j.1365-2222.2008.03151.x

150. Marone G, Spadaro G, Braile M, Poto R, Criscuolo G, Pahima H. Tezepelumab: a novel biological therapy for the treatment of severe uncontrolled asthma. Expert Opin Invest Drugs (2019) 28:931-40. doi: 10.1080/13543784.2019.1672657

151. Gauvreau GM, O’Byrne PM, Boulet LP, Wang Y, Cockcroft D, Bigler J, et al. Effects of an anti-TSLP antibody on allergen-induced asthmatic responses. N Engl J Med (2014) 370:2102-10. doi: 10.1056/NEJMoa1402895
152. Corren J, Parnes JR, Wang L, Roseti SL, Griffiths JM, van der Merwe R. Tezepelumab in adults with uncontrolled asthma. N Engl J Med (2017) 377:936-46. doi: 10.1056/NEJMoa1704064

153. Murakami-Satsutani N, Ito T, Nakanishi T, Inagaki N, Tanaka A, Vien PT, et al. IL-33 promotes the induction and maintenance of Th2 immune responses by enhancing the function of OX40 ligand. Allergol Int (2014) 63:443-55. doi: 10.2332/allergolint.13-OA-0672

154. Barlow JL, Peel S, Fox J, Panova V, Hardman CS, Camelo A, et al. IL-33 is more potent than IL-25 in provoking IL-13-producing nuocytes (type 2 innate lymphoid cells) and airway contraction. J Allergy Clin Immunol (2013) 132:933-41. doi: 10.1016/j.jaci.2013.05.012

155. Kaur D, Gomez E, Doe C, Berair R, Woodman L, Saunders R, et al. IL-33 drives airway hyper-responsiveness through IL-13-mediated mast cellairway smooth muscle crosstalk. Allergy (2015) 70:556-67. doi: 10.1111/ all. 12593

156. Pelaia C, Crimi C, Vatrella A, Busceti MT, Gaudio A, Garofalo E, et al. New treatments for asthma: from the pathogenic role of prostaglandin $\mathrm{D}_{2}$ to the therapeutic effects of fevipiprant. Pharmacol Res (2020) 155:104490. doi: 10.1016/j.phrs.2019.104490

157. Gonem S, Berair R, Singapuri A, Hartley R, Laurencin MFM, Bacher G, et al. Fevipiprant, a prostaglandin $\mathrm{D}_{2}$ receptor 2 antagonist, in patients with persistent eosinophilic asthma: a single-centre, randomized, double-blind, parallel-group, placebo-controlled trial. Lancet Respir Med (2016) 4:699-707. doi: 10.1016/S2213-2600(16)30179-5

158. Bateman ED, Guerreros AG, Brockhaus F, Holzhauer B, Pethe A, Kay RA, et al. Fevipiprant, an oral prostaglandin $\mathrm{DP}_{2}$ receptor (CRTh2) antagonist, in allergic asthma uncontrolled on low-dose inhaled corticosteroids. Eur Respir $J$ (2017) 50:1700670. doi: 10.1183/13993003.00670-2017

159. Kalchiem-Dekel O, Yao X, Levine SJ. Meeting the challenge of identifying new treatments for type 2-low neutrophilic asthma. Chest (2020) 157:26-33. doi: 10.1016/j.chest.2019.08.2192

160. Nair P, Prabhavalkar KS. Neutrophilic asthma and potentially related target therapies. Curr Drug Targets (2020) 21:374-88. doi: 10.2174/ 1389450120666191011162526

161. Busse WW, Holgate S, Kerwin E, Chon Y, Feng J, Lin J, et al. Randomized, double-blind, placebo-controlled study of brodalumab, a human anti-IL-17 receptor monoclonal antibody, in moderate to severe asthma. Am J Respir Crit Care Med (2013) 188:1294-302. doi: 10.1164/rccm.201212-2318OC

Conflict of Interest: The authors declare that the research was conducted in the absence of any commercial or financial relationships that could be construed as a potential conflict of interest.

Copyright (c) 2020 Pelaia, Crimi, Vatrella, Tinello, Terracciano and Pelaia. This is an open-access article distributed under the terms of the Creative Commons Attribution License (CC BY). The use, distribution or reproduction in other forums is permitted, provided the original author(s) and the copyright owner(s) are credited and that the original publication in this journal is cited, in accordance with accepted academic practice. No use, distribution or reproduction is permitted which does not comply with these terms. 